\title{
ASSOCIATION BETWEEN HANDLING STRESS IN THE CORRAL AND RABIES ANTIBODY TITERS IN SELENIUM-SUPPLEMENTED CATTLE
}

\section{Reis LSLS (1), Chiacchio SB (2), Oba E (3), Pardo PE (4), Frazatti-Gallina NM (5)}

(1) Graduate Program in Veterinary Medicine, Veterinary Medicine and Animal Husbandry School, São Paulo State University, UNESP, Botucatu, São Paulo State, Brazil; (2) Department of Veterinary Clinic, Veterinary Medicine and Animal Husbandry School, São Paulo State University, UNESP, Botucatu, São Paulo State, Brazil; (3) Department of Animal Reproduction and Veterinary Radiology, Veterinary Medicine and Animal Husbandry School, São Paulo State University, UNESP, Botucatu, São Paulo State, Brazil; (4) Department of Veterinary Clinics, University of Western São Paulo, UNOESTE Presidente Prudente, São Paulo State, Brazil; (5) Rabies Laboratory, Butantan Institute, São Paulo, São Paulo State, Brazil.

ABSTRACT: This study determined the correlation between serum cortisol levels and rabies antibody titers in cattle primo-vaccinated against rabies and supplemented with dietary selenium (Se). Sixty Nelore male calves (10 to 12 months old) received daily and individual dietary supplementation with $0,3.6,5.4$ and $6.4 \mathrm{mg}$ Se (groups $\mathrm{Gc}, \mathrm{G}_{3.6}, \mathrm{G}_{5.4}$ and $\mathrm{G}_{6.4}$, respectively). The animals were vaccinated against rabies (day 0 ) and subjected to handling stress in the corral for 120 days. Blood sampling procedures were performed on days 0, 15, 30, 60, 90 and 120. Cortisol levels increased until day 90 , but had dropped significantly by day 120 ( $P<$ 0.01). Rabies antibody titers on days 30 and 90 were similar among Sesupplemented groups; in the control group, rabies antibodies decreased significantly from day 30 to 60, and 90 to 120 . Serum cortisol levels and antibody titers were not correlated in most of the groups or blood sampling days. A positive correlation among these variables was found only in $G_{6.4}$ on days $60(R=0.513 ; P=0.05)$ and $120(R=0.644 ; P=0.009)$. In conclusion, repeated handling in the corral stresses cattle, but without compromising rabies humoral immune response.

KEY WORDS: cattle, cortisol, stress, rabies immune response, selenium supplementation.

CONFLICTS OF INTEREST: There is no conflict.

FINANCIAL SOURCE: Matsuda Sementes e Nutrição Animal.

\section{CORRESPONDENCE TO:}

LUIS SOUZA LIMA DE SOUZA REIS, rua Osvaldo Cruz 2027, Bairro Ouro Verde, Assis, SP, 19800-081, Brazil. Phone: +55 18 9776-2550. Email: reis.Isls@gmail.com. 


\section{INTRODUCTION}

Rabies infection, provoked by a virus (genus Lyssavirus, family Rhabdoviridae) and transmitted primarily by Desmodus rotundus bats, results in untreatable and fatal encephalitis in mammals (1-3).

The large-scale and regular vaccination of cattle is an efficient low-cost method that prevents and controls rabies infection, minimizing economic losses $(1,4,5)$. However, inappropriate stimulation is employed during cattle vaccination, such as driving animals from pasture to corral, physical exercises forced during handling in the corral, exposure of animals to the corral environment, the presence and shouts of the stockman as well as pain from vaccine application (6-11).

Stressors activate the hypothalamus-pituitary-adrenal (HPA) axis that stimulates the adrenal glands to release hormones including cortisol, epinephrine and noradrenalin $(12,13)$. High levels of blood cortisol provoke immunosuppression, rendering the cattle more susceptible to infectious diseases $(12,14)$. Moreover, vaccinated animals may be vulnerable to infectious diseases if minimum antibody protection levels are not reached.

In addition, the lack of nutrients, such as selenium (Se), account for cattle susceptibility to these infections. Selenium deficiency is associated with low resistance, i.e., decreased antibody production and lymphocyte proliferation $(15,16)$. Selenium is scarce globally, although it is essential to many organic functions, based on its antioxidant properties and its incorporation in selenoproteins such as glutathione peroxidases (GSH-Px) that protect cell membranes against free radical damage and eliminate peroxides from blood and extracellular space $(15,16)$. The present study investigated the effect of Se-supplemented diets on anti-rabies humoral response of Nelore (Zebu) cattle under handling stress. This was achieved by correlating serum cortisol levels and rabies antibody titers.

The experiment was carried out from February to June 2007, in Lutécia, São Paulo state, Brazil. Sixty Nelore cattle (Bos taurus indicus), aged between 10 and 12 months, were maintained on an extensive pasture system in which they grazed on Brachiaria decumbens forage. The cattle were randomly divided into four groups (15 animals each). All groups were fed ad libtum Top Line Recria ${ }^{\circledR}$ protein mineral mixture (Matsuda Sementes e Nutrição Animal Ltda., Brazil), approved by the Brazilian Ministry of Agriculture, Livestock and Food Supply (MAPA). The control group (Gc) was fed exclusively this diet while the other groups received this mixture 
supplemented with daily concentrations of $3.6,5.4$ or $6.4 \mathrm{mg}$ of $\mathrm{Se}$ (groups $\mathrm{G}_{3.6}, \mathrm{G}_{5.4}$ and $\mathrm{G}_{6.4}$, respectively). Given that each animal consumes about $200 \mathrm{~g}$ of mineral mixture per day (as measured during the experiment), diets for groups $G_{3.6}, G_{5.4}$ and $\mathrm{G}_{6.4}$ included, respectively, 18, 27 and $32 \mathrm{mg}$ of selenium per kilogram.

Each experimental group was kept in a paddock (100 kg live weight/ha) in a continuous grazing system with groups rotated among the four paddocks every 30 days. The fields had similar topography and were covered with Brachiaria decumbens. The mineral mixture was offered in covered wooden feeders $(13 \mathrm{~cm}$ length, available for each animal), while water was placed $50 \mathrm{~m}$ from the feeders.

After 30 days of cattle adjustment to management conditions and to experimental diets, animals were primo-vaccinated against rabies on day 0 . Over the next 120 days, the cattle underwent five handling sessions for blood collection (on days 15, 30, 60, 90 and 120). Blood samples were employed to determine serum cortisol and rabies antibody titers.

Handling stress was imposed on cattle in the morning, while animals were being prepared for vaccination and blood sampling. The stressors consisted of the following stimuli commonly used in livestock practices: driving from pasture to the corral, time spent in the corral, the presence of a shouting stockman, rabies vaccination or blood sampling, forced movement in the corral, restraint of animals in a stun box for five minutes.

The rabies vaccine was subcutaneously injected in individual $2-\mathrm{mL}$ doses. This inactivated commercial vaccine (Alurabiffa ${ }^{\circledR}$, Merial, Brazil), approved by MAPA, is indicated for cattle and consists of a Pasteur-fixed rabies virus (PV) suspension, replicated in BHK 21 clone-13 cells.

Blood was collected by puncture from the jugular vein into 10-mL vacuum tubes, without anticoagulant. Blood samples were centrifuged at 2,500 rpm for 10 minutes; subsequently, serum samples were stored in $1.5-\mathrm{mL}$ tubes at $-20^{\circ} \mathrm{C}$. Commercial kits for solid phase radioimmunoassay (Coat-A-Count ${ }^{\circledR}$, Diagnstic Products Corporation, USA) and Cobra II Gamma Counter ${ }^{\circledR}$ (Packard Bio Sciences, USA) were utilized to determine serum cortisol levels. Serum neutralization of BHK 21 clone-13 cells was used to determine rabies neutralizing antibody titers, according to the rapid fluorescent focus inhibition test (RFFIT) and the fluorescent inhibition microtest (FIMT) $(17,18)$. 
On day 0 , forage samples from all paddocks were collected and stored at $-5^{\circ} \mathrm{C}$. Selenium concentration was determined from these samples through graphite furnace atomic absorption spectrophotometry.

Serum cortisol concentrations were compared among groups ( $\mathrm{Gc}, \mathrm{G}_{3.6}, \mathrm{G}_{5.4}$ and $\mathrm{G}_{6.4}$ ) and days of observation ( $T_{0}, T_{15}, T_{30}, T_{60}, T_{90}$ and $\left.T_{120}\right)$ by repeated measure analysis of variance followed by the least significant difference (LSD) test to compare significant differences (19). An alpha error of 0.05 was set for all tests.

Data on rabies antibody titers contradicted normal predictions (Kolmogorov-Smirnov test) and were, therefore, analyzed using Friedman non-parametric test that examined these titers temporally within each group (19). An alpha error of 0.05 was established for the tests.

Serum cortisol levels and rabies antibody titers were correlated using Spearman's non-parametric correlation (R) (19). Sixteen correlations were tested for the different groups and blood sampling days. An alpha error of 0.05 was set for all the tests.

Serum cortisol concentrations were not affected by selenium supplementation $\left(F_{(3,65)}\right.$ $=0.35 ; \mathrm{P}=0.79$; data pooled for each day of observation) nor by any interactions between selenium concentration and time $\left(F_{(15,280)}=1.41 ; P=0.14\right)$. Concerning the overall temporal effect, serum cortisol levels increased gradually in all groups throughout the study (ANOVA; $F_{(5,280)}=32.65$; $P=0.01$ ). Cortisol levels had peaked by day 90 and had decreased by day 120 (Figure 1). Rabies antibody titers were constant from day 30 to 90 in groups $G_{3.6}, G_{5.4}$ and $G_{6.4}$, but decreased in $G c(P<$ 0.05) from day 30 to day 60 onward (Figure 2). Only two positive correlations between serum cortisol levels and rabies antibody titers were detected, on days 60 and 120 , in group $\mathrm{G}_{6.4}$. No other correlation was found among the groups or on blood sampling days (Table 1). The selenium concentration in paddock forage was $0.04 \mathrm{mg}$ $\mathrm{Se} / \mathrm{kg}$. 


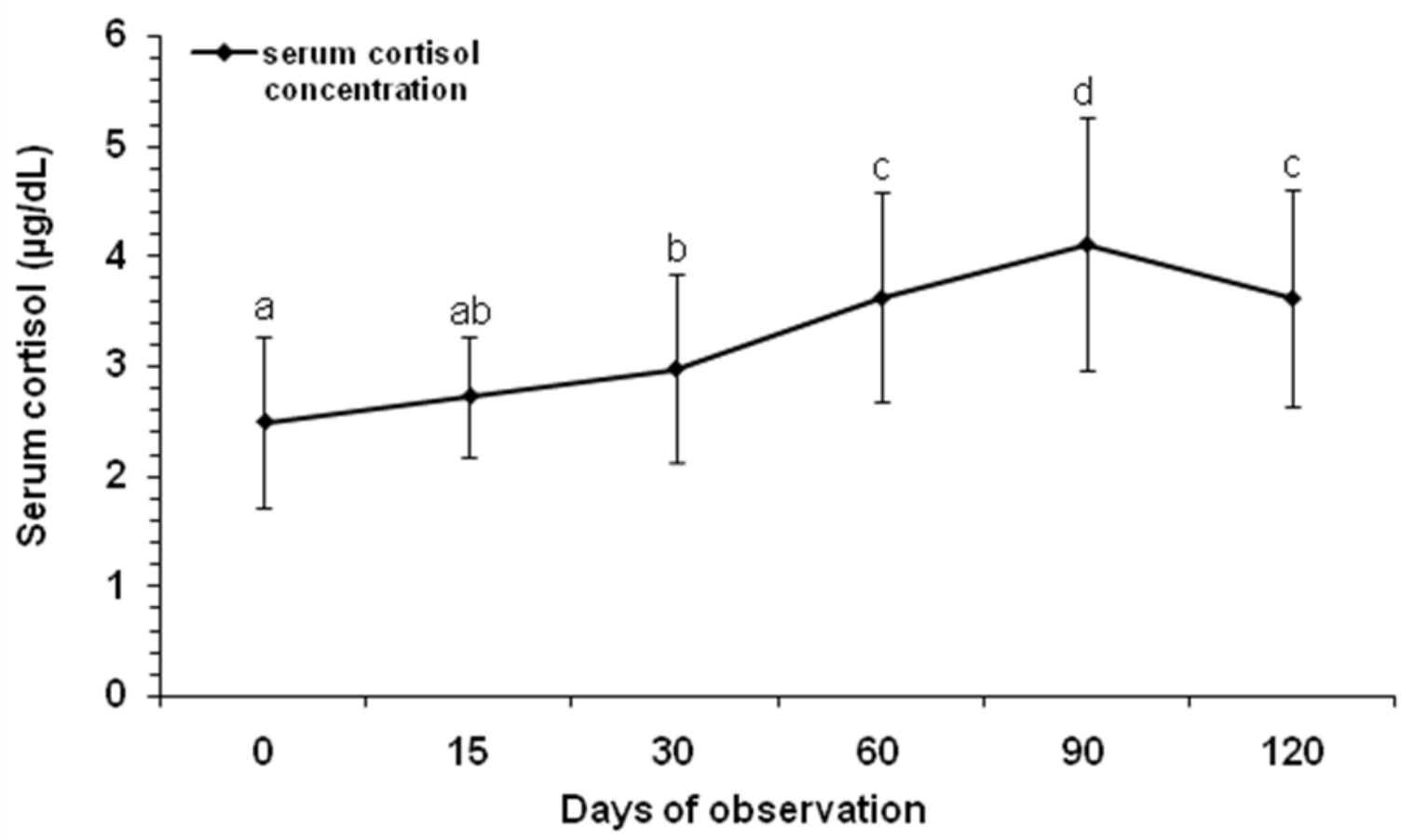

Figure 1. Mean serum cortisol levels $( \pm S D)$ in cattle throughout repeated handling procedures. Data were pooled for groups $\mathrm{Gc}, \mathrm{G}_{3.6}, \mathrm{G}_{5.4}$ and $\mathrm{G}_{6.4}$. Means sharing at least one same letter were statistically equal (ANOVA; $F_{(5,280)}=32.65 ; P=0.01 ; L S D$, $\mathrm{P}<0.01)$. 

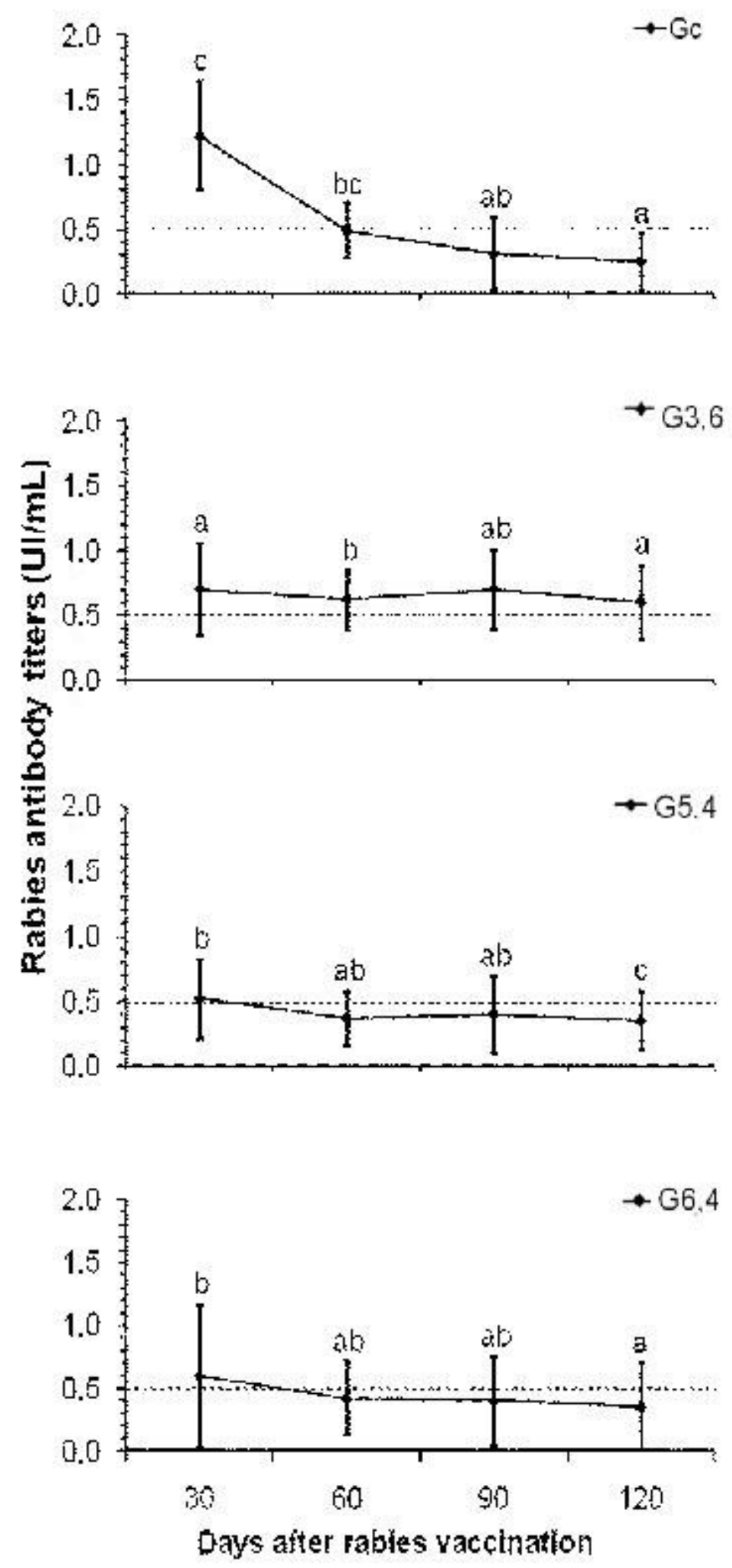

Figure 2. Median rabies antibody titers ( \pm quartile) in Nelore cattle primo-vaccinated and supplemented with daily concentrations of $0(\mathrm{Gc}), 3.6\left(\mathrm{G}_{3.6}\right), 5.4\left(\mathrm{G}_{5.4}\right)$ or 6.4 $\left(\mathrm{G}_{6.4}\right) \mathrm{mg}$ of selenium. 
Table 1. Spearman's correlation coefficient $(R)$ for serum cortisol levels and rabies antibody titers

\begin{tabular}{c|c|c|c|c}
\hline \multirow{2}{*}{ Groups } & \multicolumn{3}{|c}{ Handling/blood collection } \\
\cline { 2 - 5 } & Day 30 & Day 60 & Day 90 & Day 120 \\
\cline { 2 - 5 } & $-0.027^{\mathrm{NS}}$ & $-0.030^{\mathrm{NS}}$ & $0.121^{\mathrm{NS}}$ & $-0.034^{\mathrm{NS}}$ \\
\hline $\mathrm{G}_{3.6}$ & $0.193^{\mathrm{NS}}$ & $-0.261^{\mathrm{NS}}$ & $-0.352^{\mathrm{NS}}$ & $0.077^{\mathrm{NS}}$ \\
\hline $\mathrm{G}_{5.4}$ & $-0.057^{\mathrm{NS}}$ & $-0.272^{\mathrm{NS}}$ & $0.087^{\mathrm{NS}}$ & $-0.371^{\mathrm{NS}}$ \\
\hline $\mathrm{G}_{6.4}$ & $0.294^{\mathrm{NS}}$ & $0.513^{*}$ & $0.177^{\mathrm{NS}}$ & $0.645^{\star}$ \\
\hline
\end{tabular}

* $=\mathrm{P}<0.05 ; \mathrm{NS}=$ not significant

\section{DISCUSSION}

Variation in serum cortisol levels and antibody titers in cattle were obtained exclusively from diets and stress conditions employed. Baseline cortisol levels at the beginning of the experiment (day 0) were near the 3.29- $\mu \mathrm{g} / \mathrm{dL}$ reference value for Zebu cattle and $3.68 \mu \mathrm{g} / \mathrm{dL}$ for the Nelore breed (20-22). In addition, blood samples from day 0 were not positive for rabies, indicating that animals had no prior contact with the rabies virus or vaccine. Finally, selenium from paddock forage did not affect the results, since its value comprised only half of the $0.1 \mathrm{mg} / \mathrm{kg}$ concentration recommended by the National Research Council (NRC) to supply beef cattle needs (23).

Stressed cattle present supernormal serum cortisol levels (12, 13, 22, 24, 25). Therefore, cortisol elevation throughout the experiment indicates that from day 30 onward, animals entered a stress state due to handling conditions, regardless of treatment. In fact, after a stress peak on day 90, cortisol levels had dropped by day 120 and baseline values $(3.68 \mu \mathrm{g} / \mathrm{dL})$ were reestablished (Figure 1), suggesting that cattle may have adjusted to handling stress $(10,22,26,27)$.

Despite cortisol increase, handling stress did not compromise rabies humoral immune response (Figure 2). This finding corroborates other studies in which humoral immune response of cattle against the leucotoxin Mannheimia haemolytica was not affected by transportation stress while the reaction against the tetanous toxoid was not altered by vaccination stress $(14,28)$. In contrast, social isolation compromises the response of 12-week old calves to experimental infection with bovine herpesvirus 1 (29). Besides animal age, the nature of stress agents may account for these divergent data, i.e., calves are more vulnerable to social stress 
than to handling stress. This is an important finding, since handling stress is very common during the regular vaccination required for rabies control.

By the end of the study, rabies antibody titers had decreased in most of the groups (Figure 2), as expected for primo-vaccinated cattle (30-34). In contrast, these antibody titers were sustained in group $G_{3.6}$ that received selenium supplementation close to $3 \mathrm{mg} /$ day, the dose recommended by the NRC for taurine breeds (23). Therefore, this supplementation concentration is appropriate for both taurine and Zebu breeds.

Both cortisol levels and antibody titers decreased during the studied period, but in general these variables were not correlated to each other. This fact supports the finding that stress does not influence rabies humoral immune response in cattle. Only group $\mathrm{G}_{6.4}$ presented a positive correlation between these variables on days 60 and 120 (Table 1). In this group, handling stress was possibly related to augmented immune response, although this was not maintained until day 120 , when rabies antibody titers of $\mathrm{G}_{6.4}$ dropped under the minimum protective levels (Figure 2).

Further investigation is required to determine the physiological mechanisms that mediate the relationship between cortisol levels and antibody titers. However, selenium supplementation at $6.4 \mathrm{mg} /$ day may be excessive and likely to compromise rabies humoral response.

In conclusion, repeated handling in the corral stresses cattle, but does not diminish the antibody titer after rabies vaccination.

\section{ACKNOWLEDGEMENTS}

We are thankful to Matsuda Sementes e Nutrição Animal, Álvares Machado, São Paulo state, Brazil, for supporting and encouraging this study.

\section{REFERENCES}

1. Consales CA, Bolzan VL. Rabies review: immunopathology, clinical aspects and treatment. J Venom Anim Toxins incl Trop Dis. 2007;13(1):5-38.

2. Ackar SM, Sinhorini IL, Ribeiro OG, Carrieri ML, Ceretta RS, Consales CA. Immunopathology of rabies infection in mice selected for high or low acute inflammatory reaction. J Venom Anim Toxins incl Trop Dis. 2007;13(1):39-55. 
3. Dantas-Torres F. Bats and their role in human rabies epidemiology in the Americas: review. J Venom Anim Toxins incl Trop Dis. 2008;14(2):193-202.

4. Aguilar-Setién A, Leon YC, Tesoro EC, Kretschmer R, Brochier B, Pastoret PP. Vaccination of vampire bats using recombinant vaccinia-rabies virus. $\mathrm{J}$ Wildl Dis. 2002;38(3):539-44.

5. Albas A, Fontolan OL, Pardo PE, Bremer-Neto H, Sartori A. Interval between first dose and booster affected antibody production in cattle vaccinated against rabies. $\mathrm{J}$ Venom Anim Toxins Incl Trop Dis. 2006;12(3):476-86.

6. García-Belenguer S, Palacio J, Gascón M, Aceña C, Revilla R, Mormède P. Differences in the biological stress responses of two cattle breeds to walking up to mountain pastures in the Pyrenees. Vet Res. 1996;27(4-5):515-26.

7. Paludo GR, McManus C, Melo RQ, Cardoso AG, Mello FPS, Moreira M, et al. Efeito do estresse térmico e do exercício sobre parâmetros fisiológicos de cavalos do exército brasileiro. Rev Bras Zootec. 2002;31(3):1130-42.

8. Arthington JD, Eicher SD, Kunkle WE, Martin FG. Effect of transportation and commingling on the acute-phase protein response, growth, and feed intake of newly weaned beef calves. J Anim Sci. 2003;81:1120-5.

9. Hemsworth PH, Coleman GJ, Barnett JL, Borg S, Dowling S. The effects of cognitive behavioral intervention on the attitude and behavior of stockpersons and the behavior and productivity of commercial dairy cows. J Anim Sci. 2002;80(1):6878.

10. Hickey MC, Drennan M, Earley B. The effect of abrupt weaning of suckler calves on the plasma concentrations of cortisol, catecholamines, leukocytes, acute-phase proteins and in vitro interferon-gamma production. J Anim Sci. 2003;81(11):2847-55.

11. von Borell EH. The biology of stress and its application to livestock housing and transportation assessment. J Anim Sci. 2001;79(E. Suppl.):E260-E267.

12. Gupta S, Earley B, Crowe MA. Pituitary, adrenal, immune and performance responses of mature Holstein $x$ Friesian bulls housed on slatted floors at various space allowances. Vet J. 2007;173(3):594-604.

13. Curley Jr KO, Neuendorff DA, Lewis AW, Cleere JJ, Welsh Jr TH, Randel RD. Functional characteristics of the bovine hypothalamic-pituitary-adrenal axis vary with temperament. Horm Behav. 2008;53(1):20-7. 
14. Stanger KJ, Ketheesan N, Parker AJ, Coleman CJ, Lazzaroni SM, Fitzpatrick LA. The effect of transportation on the immune status of Bos indicus steers. J Anim Sci. 2005;83(11):2632-6.

15. Carvalho FAN, Barbosa FA, McDowell LR. Minerais. In: Carvalho FAN, Barbosa FA, McDowell LR, editors. Nutrição de bovinos a pasto. Belo Horizonte: Papel Form Editora Ltda; 2003. p. 157-368.

16. Carroll JA, Forsberg NE. Influence of stress and nutrition on cattle immunity. Vet Clin North Am Food Anim Pract. 2007;23(1):105-49.

17. Smith JS, Yager PA, Baer GM. A rapid fluorescent focus inhibition test (RFFIT) for determining rabies virus-neutralizing antibody. In: Mestin FX, Kaplan MM, Koprowski $\mathrm{H}$, editors. Laboratory techniques in rabies. $4^{\text {th }}$ ed. Geneva: World Health Organization; 1996. p. 181-92.

18. Zalan E, Wilson C, Pukitis D. A microtest for the quantitation of rabies virus neutralizing antibodies. J Biol Stand. 1979;7(3):213-20.

19. Zar JH. Biostatistical analysis. New Jersey: Prentice Hall; 1999. 663 p.

20. Aragón Vasquez EF, Graça DS, Norte AL, Santiago GS, Paula OJ. Suplementação com cromo e desempenho reprodutivo de vacas zebu primíparas mantidas a pasto. Arq Bras Med Vet Zootec. 2001;53(5):624-8.

21. Aragón Vasquez EF, Naranjo Herrera AP. Concentração plasmática de cortisol, uréia, cálcio e fósforo em vacas de corte mantidas a pasto suplementadas com levedura de cromo durante a estação de monta. Ciênc Rural. 2003;33(4):743-7.

22. Reis LS, Pardo PE, Oba E, Kronka Sdo N, Frazatti-Gallina MN. Matricaria chamomilla $\mathrm{CH} 12$ decreases handling stress in Nelore calves. J Vet Sci. 2006;7(2):189-92.

23. National Research Council - NRC. Nutrient requirements of beef cattle. Washington: National Academy Press; 2000. p. 54-74.

24. Hopster H, Van Der Werf JTN, Erkens JHF, Blokhuis HJ. Effects of repeated jugular puncture on plasma cortisol concentrations in loose-housed dairy cows. J Anim Sci. 1999;77(3):708-14.

25. Acaro Jr I, Acaro JRP, Pozzi CR, Fagundes H, Matarazzo SV, Oliveira CA. Teores plasmáticos de hormônios, produção e composição do leite em sala de espera climatizada. Rev Bras Eng Agríc Ambient. 2003;7(2):350-4. 
26. Mellor DJ, Stafford KJ, Todd SE, Lowe TE, Gregory NG, Bruce RA, Ward RN. A comparison of catecholamine and cortisol responses of young lambs and calves to painful husbandry procedures. Aust Vet J. 2002;80(4):228-33.

27. Solano J, Galindo F, Orihuela A, Galina CS. The effect of social rank on the physiological response during repeated stressful handling in Zebu cattle (Bos indicus). Physiol Behav. 2004;82(4):679-83.

28. Wernicki A, Urban-Chmiel R, Mikucki P, Puchalski A, Kankofer M. The influence of transport stress on the humoral immunological response of calves induced by Mannheimia haemolytica leukotoxin. Pol J Vet Sci. 2003;6(1):41-5.

29. Van Reenen CG, Mars MH, Leushuis IE, Rijsewijk FAM, Van Oirschot JT, Blokhuis $\mathrm{HJ}$. Social isolation may influence responsiveness to infection with bovine herpes virus 1 in veal calves. Vet Microbiol. 2000;75(2):135-43.

30. Ciuchini F, Irsara A, Pestalozza S, Trani L, Antonucci G. Risposta immunitaria in bovini vaccinati contro la rabia com virus atenuado ceppo ERA. Riv Zootec Vet. 1981;9(3):176-84.

31. Oliveira AN, Andrade MCR, Silva MV, Moura WC, Cortez Contreiras E. Immune response in cattle vaccinated against rabies. Mem Inst Osvaldo Cruz. 2000;95(1):838.

32. Rodrigues da Silva AC, Caporale GMM, Gonçalves CA, Targueta MC, Comin F, Zanetti CR, Kotait I. Antibody response in cattle after vaccination with inactivated and attenuated rabies vaccines. Rev Inst Med Trop São Paulo. 2000;42(2):95-8.

33. Albas A, Pardo PE, Bremer-Neto H, Gallina NMF, Mourão Fuches RM, Sartori A. Vacinação anti-rábica em bovinos: comparação de cinco esquemas vacinais. Arq Inst Biol. 2005;72(2):153-9.

34. Giometti J, Chiacchio SB, Albas A, Pardo PE, Bremer-Neto H, Giometti Al, Reis LSLS. Influência da suplementação com crômio na resposta imune humoral antirábica em Bovinos. Arq Inst Biol. 2006;73(4):421-7. 